lishing seed collection offices and of making available experimental lots of seeds of native forest tree spocios to other interested countries and the necessity of promoting effective schomes for the certification of tree se日ds and plants both in internal and external trade.

Sixteen recommendations were made to tho Food and Agriculture Organization and the International Union of Forest Research Organizations. They include the suggestion that the Food and Agriculture Organization should explore the possibility of setting up an advisory and information unit on the introduction of forest troes with actual or potentiol use as exotics, that the International
Union of Forest Research Organizations should establish a special working group on tree physiology, and that further work should be encouraged on tree cytology and on the interactions between genotypes. The various recommendations underline the fact that the forest geneticist and the tre breeder are concerned with the forestis of the world and with follow scientists everywhere even if the particular problem is relative to a small area only. Thus co-operation is the key to the work, and such a useful conference as took placo in Sweden and which was attended by 155 registered participants from 34 countries should do a great deal to achieve this, C. J. TAYLOR

\title{
EXCESS FUNCTIONS IN MOLTEN SALTS
}

A

ONE-DAY discussion on excess functions in molten salts was held under the auspices of the Faraday Society, in the Department of Chemical Engineering and Chemical Technology, Imperial College of Science and Technology, on February 25. The chairman was Prof. A. R. Ubbelohde. There were four invited contributions.

Molten halides. Dr. E. R. Buckle (Imperial Colloge of Science and Technology) presented recent work on the excess volumes of mixing $(V E)_{M}$ of thallium halides with alkali halides. $(V E)_{M}$ in cortain cases is very largo (5 per cent or more, for example, potussium bromide-thallium bromide). Most systems show a change from a negative excess volume at low-melting temperatures (about $650^{\circ} \mathrm{C}$, depending on the liquidus of the mixtures) to relatively large positive deviations at higher temperatures (about $750^{\circ} \mathrm{C}$ ), for example. thallium chloride-potassium chloride. Some systems, at intermediate temperaturos, show both positive and negative excess volumes. By contrast, mixtures of rubidium bromide-thallium bromido are nearly ideal with deviations only just outside the limits of experimental error ( $\pm 0 \cdot 1$ per cent). Dr. J. L. Holm (Trondheirn) spoko about various theories for calculating and correlating excess data in molten salt mixtures. For regular solutions the Flood and Forland modifications of the Temkin theory seemed to be most succossful, and enable ono to calculate free energies of mixing from phase rule data. Kleppa's calorimetric data for the excess hoats of mixing could be fitted by means of adjustable parameters to the modified conformal solution theory developed by Reiss, Katz and Kloppa. Using cryoscopio data, and the modified Temkin regular solution theory of mixing, the calculated free energies of mixing, $Q E$, of alkali fluorides showed both positive and negative deviations from ideality. It was suggested that the positive deviations were prodominantly ceused by the relative unscreoning of the cations due to the small size of the anions. Excess enthalpies of mixing for lithium fluoride-sodium fluoride and lithium fluoride potassium fluoride mixtures were negative. Excess entropies of mixing of lithium, sodium and potassium chlorides and bromides were in the rango -0.02 e.u. to -0.11 e.u. +0.05 e.u. Errors in the estimates of excess entropies were primarily due to inaccuracies in calculations of the free energies of mixing.

In discussion, various postulates such as: complex-ion formation, packing modifications and changos in the ionic eharactor of the cation were put forward to account for the complex excess volumo changes in the thallium halide systems. No definite conclusions were reachod, and it is obvious that further accurate thermodynamic data and now techniques for examining localized interactions in molten salts are noeded. Vapour pressure mothods might be suitable for this purpose, though there are difficulties in specifying the moleculos in vapours from salts.

It was pointed out that theories developed for molecular liquids aro not strictly applicable to molten salt mixtures, since cations polarize the anions, induoing dipoles, and these also interact. Systems containing a common cation and several anions might behave more like mixturos of molecular liquids. There is need for an agreod definition of a 'complex' in molten salts: Is it just a statistical grouping of ions, or is it a long-lived entity? If 'complexes' exist as a long-lived entity in the system, a useful technique for revealing their presence might be their Raman spectra.

Melts with polyatomic anions. Dr. E. Rhodos (Imperial Colloge of Science and Technology) presented fresh information about exoess volumes of mixing of alkali and alkaline carth nitrates. In contrast with halide mixtures, these show zero excess volumes of mixing (to an accuracy of \pm 0.1 per cent). Extrapolation of the molar volume/composition isotherms and thermal expansion/composition plots gave identioal values for the partial equivalent volumes of any onc alkaline earth nitrate in any alkali nitrato. This finding, coupled with the fact that the equivalent volumes of calcium nitrate and magnesium nitrate are identical at their respective freezing points, suggests the applicability of a model for molten nitrates based on a plasma of nitrate ion spheres in contact, arranged as in a cubic close-packed crystal lattice. The total solid volume occupied by cations in a $50: 50$ equivalont per cent mixture of potassium nitrate-calcium nitrate is only 14 per cent of that occupied by the nitrate anions, so it is only to be expected that the volumes of mixing are practically ideal. These ideal volumes of mixing are in sharp contrast with the large excess enthalpies found by Kleppa et al, (up to 5 kcal). However, spectroscopic evidence indicates that cations aro closer to the anions in these mixtures than would be expected if the cations occupied their correct positions on a crystalline lattice as postulated in the Temkin regular solution theory. The resulting increased polarization of the anions could contribute large excess energy terms to the heat of mixing.

Dr. B. de Nooÿer (Amstordam) presented recent work on the measurement of free energies of mixtures of silver nitrate with alkali nitrates. An electromotive force cell was used in which the anode was a $\mathrm{NO}_{3}$ - electrode, thus eliminating unknown transference effects. The stability of the nitrate electrode was $\pm 1.5 \mathrm{mV}$ or about $\pm 35 \mathrm{cal}$. The overall reaction is :

$$
\mathrm{Ag}+\mathrm{NO}_{2}+\frac{1}{2} \mathrm{O}_{2} \rightarrow \mathrm{Ag}^{+}+\mathrm{NO}_{3}^{-}
$$

Using the usual formulae, the exeess free-energy of mixing, $G E$, could be calculated from the ideal and real electromotive forco of the cell. Kleppa's calorimetric excess enthalpies for mixing silver nitrato with various alkali nitrates are all positive. The newly determined excess free-energies are positive for lithium nitrate or sodium nitrate mixed with silver nitrate, and negative for potassium nitrate or rubidium nitrate. Entropies of mixing 
aro all negativo. Electrical conductivitios of molten salt mixtures containing lithium ions showed definite deviations from additivity.

A description was givon by Prof. M. Chemla (Paris) of measurements on diffusion and electrical mobility of cations in various halide or nitrato melts containing lithium, sodium, and potassium. The Nornst-Einstein relation was not obeyod, and relative mobilities of the ions changed with increasing tomporature. The rosults suggested formation of complexes or incipient clusters, the size of which decreasod and number incroased with increasing temperature. Queries wero raised about the validity of the method usod (counter-current electromigration) in detormining rolative ionic mobilities, and about the strict applicability of the Nernst-Einstein relation to molten salts.

The importance of measuroments of the tomporature dependence of the excess hoats of mixing was emphasized. Direct experimental values of excess functions would bo more helpful than indiroct measurements. Any statistical theory would give the excess free-onergy, $G E$, as a function of temperaturo, $T$, pressure, $P$, and composition, $x$.
Since critical points cannot be determined, the theory of corresponding states is not applicable to melts. Lattice theory applied at constant pressure tends to be uninformative, but constant volume measurements ought to be more useful. Experimental methods are now available for obtaining both first and second dorivatives of $G E$, but there is no satisfactory theory for $G E$ itself. This is unfortunate since it is very difficult to construct sensitive partition function theory for liquids based on socond derivatives.

It was roported that the heat of solution of water moleculos in lithium, sodium, potassium nitrato mixtures had been found to bo about $14 \mathrm{kcal}$. If the greater part of the solution energy is due to ion-dipolo interaction, the experimental rosults are in good agreement with theory. Finally, various speakers urged tho neod for an effort to correlato and assess the relative accuracy of various thermodynamic data available on molten salts. At the present time, thermodynamic data of increasing accuracy is gradually becoming available, but a satisfactory theoretical doscription of excess functions of molten salts is still lacking.
A. R. UBBELOHDE

\section{PLANT WAXES AND CUTINS}

A ONE-DAY moeting on "Plant Waxes, Cutins and Associated Compounds" was organized by the Phytochemical Group at the Sehool of Pharmacy, London, on January 7. The object of the meeting was to review the progress that has been made in this field since the 'thirties whon Prof. A. C. Chibnall and his colleagues separatod and idontified the odd- and even-numbered long-chain fatty acids in plant waxes. Tho chairman, Dr. G. S. Hartley (Chosterfield Park Research Station, Saffron Walden), in his opening remarks, roferrod to the very considerable comploxity of leaf surfacos and to the importance of knowing more about them, since much of present-day agriculture depended on the successful application of herbicides which would penetrate tho leaves of weeds, leaving crop plants undamaged.

A very elegant but simple method for obtaining close-up pictures of intact leaf surfaces has recently boen devoloped by Dr. B. E. Juniper (University of Oxford), who gave the opening paper. He showed electron-microscope photographs of the many difforent and complex crystalline patterns of the waxes that coat the leaf surfaces of most plants and described how loaf waxes provide a mechanism in pitcher plants for the retention of insects by preventing them from climbing out. In the second papor, Dr. G. E. Eglinton (University of Glasgow) reviewed the chemistry of leaf surface waxes, mentioning that besides the wellknown $n$-alkanes and their alcohol, aldehyde and acid derivativos, long-chain $\beta$-diketones, alkenes and branchedchain alkanos had recently boon found. Besides tho intrinsic interest of these substances as wax constituents, thero were indications, according to Dr. Eglinton, that alkane derivativos were of taxonomic value. Though there was much qualitative and quantitative variation in the chain-lengths of these hydrocarbons, their identification, by gas-phase chromatography, had become a routine matter.

Anothor technique that has been developed in recent years for separating leaf waxes is thin-layer chromatography, and in the third paper Dr. E. V. Truter (University of Loods), the pioneer in this field, described tho use of thin-layer chromatography for tho separation and analysis of the leaf waxes of the cabbage. Of the twenty-nine compounds present, the most important wore nonacosane and its rolatod primary alcohol, acid and estors. The related ketones, ketols and secondary alcohols, which woro also present, wore characterized by oxidativo fission and identification of the chain fragments by thin-layor chromatography on damp kieselguhr.

The plant cuticle, the non-cellular mombrane which covers the epidormis, appears to be chomically distinct from the wax above it. This is so, for example, in the apple fruit, which has been extensively investigatod by Dr. J. T. Martin of the Long Ashton Research Station, Bristol. While the wax contains the usual range of hydrocarbon derivatives and also the triterpenoid, ursolic acid, the cuticlo consists almost entiroly of esters of 10,16-dihydroxyhexadecanoic and 9,10,18-trihydroxyoctadecanoic acids. Dr. Martin also found tannins, quorcetin glycosides and other phenols in the cuticle, but commonted that they did not appear to participate directly in the cutin complex. The next paper, by Dr. P. Mazliak of the Sorbonne, Paris, dealt with the metabolism of apple fruit waxes. Radioactive acetate was supplied to growing applo peel and the waxes were lator saponified and analysed by gas chromatography. To his surprise, Dr. Mazliak found that, although the alcohols and acids such as linoleic and oleic acids wore labelled as expocted, there was no radioactivity in the paraffins. He obtained the same result with mature peel and could only concludo that the paraffins wore synthesized by a soparate pathway from the other wax constituents.

The final paper, by Dr. 1). F. Meigh (Ditton Laboratory, Maidstone), was concernod with the relationship betwoen apple waxos and storage disorders. He described his own investigations of superficial scald, the most important cause of wastage in the storod apple crop. Although the condition is controlled by wrapping apples in oiled tissue, its causo is as yet undetormined. Attempts to correlato the riso in concentration of linoleic acid in the apple skin at maturity with the incidence of scald have failed. Dr. Moigh did have some evidence that the paper wraps reduced the concentration of carboxyl compounds in the apple wax; another possibility was that volatile substances wore involved. It was clear from this and other papers that much more information is needed before practical problems involving leaf surfaces can be solved. As Dr. Hartley pointed out in his closing remarks to tho meeting, besides its main purpose as a skin to protect the plant from its immediate environment, the plant surface prosumably has to fulfil a range of other functions, about which we are still very ignorant.

\section{J. B. HaRborne}

